\title{
Commentary on John Gibbs' "What Do Near-Death Experiencers and Jesus Have in Common? The Near-Death Experience and Spong's New Christianity"
}

\author{
Michael B. Sabom, M.D. \\ Atlanta, GA
}

ABSTRACT: John Gibbs relates research findings on near-death experiences (NDEs) to John Shelby Spong's "continuity view of Jesus" and his "call for a new Christianity." Gibbs' argument falls short of demonstrating congruence of the scientific findings of NDE research with the theological claims of Spong, who posits that Jesus was not God, but just a person.

KEY WORDS: near-death experience; Christianity; Spong.

For the past decade or so, I have enjoyed several extended conversations with John Gibbs about our mutual interest and work in the field of near-death studies and its relationship to our religious beliefs. I have found Gibbs to be a valued friend and a deep thinker. Throughout our interaction, we have espoused clearly differing theologies I, a traditional conservative Christianity that holds to a literal and inerrant view of the Bible (Sabom, 2000b, pp. 35-40); and Gibbs, a nonsectarian, "open and evolving" view.

In "What do Near-Death Experiencers and Jesus Have in Common? The Near-Death Experience (NDE) and Spong's New Christianity" (Gibbs, 2005), Gibbs properly points out that following an NDE, persons "typically become less self-centered or more spiritual"; become

Michael B. Sabom, M.D., is a cardiologist in private practice. Reprint requests should be addressed to Dr. Sabom at 100 Wing Mill Road, Atlanta, GA 30350; e-mail: MSabom@aol.com. 
less concerned "with material self-aggrandizement or social status"; show "subsequent gains in love for others in terms of acceptance, understanding, and caring"; "report an inner sense of divine presence as well as insight into the problems of others"; and often "shift their occupation to one of the helping professions, volunteer in a social or community service, or join humanitarian causes." "In religious terms," Gibbs concludes, "one might say that near-death experiencers by virtue of their experience tend to become more Christ-like."

In Light and Death, I wrote:

In comparing the main aftereffects of the near-death experience to scriptural principles, it appears that the NDE promotes, not detracts from, belief in certain biblical principles .... It leads to an increase in a belief in God [,] ... promotes a belief in life after death $[$,$] ... en-$ courages one's concern for others, ... advances one's desire to pray, ... [a]nd it diminishes one's emphasis on the material world as recommended by Jesus in Matthew 6:25, 33-34 in which he told the crowds in his famous "Sermon on the Mount" to put the pursuit of spiritual matters ahead of material concerns. (Sabom, 1998, pp. 204-205)

In a sense, then, it can be said that the NDE leads to more "Christlike" behavior, but this behavior is not unique to Jesus' teachings. NonChristian researcher Kenneth Ring observed:

Isn't it obvious that what core NDErs experience when they come close to death is what the rest of us would call God, or if not God, then surely some aspect of the infinitude of God made manifest to the mind or spirit of the NDEr? ... If this experience is not of God, then what else could it possibly be? (Ring, 1984, p. 84)

Ring and I have found that following this experience "of God," the changes in attitude and behavior noted by Gibbs occur in the lives of Christians and nonChristians alike. Such universal changes have led me to postulate that a "general revelation of God" is occurring whereby God unveils His invisible qualities - His eternal power, divine nature, and holy law - during the NDE (Sabom, 1998, pp. 205-213). Furthermore, "[a]ll near-death experiencers are imbued with a sense of increased spiritual fervor, but the direction in which the fervor is expressed is determined by other influences .... Spiritually-charged near-death experiencers and researchers alike can thus be seen to pursue widely differing paths in search of truth and enlightenment paths which lead as easily down the road to Omega [Ring, 1984] as down the road to ... the historical Jesus, the One who proclaimed himself to be the Christ, indeed the very Son of God" (Sabom, 1998, pp. 140-141, 213, 223). The NDE carries a powerful, spiritual imprint 
of God, even in the lives of atheists (Sabom, 1998, pp. 209-210), but this imprint does not delineate any specific religious doctrine.

Keeping this in mind, let us examine Gibbs' claim that the "implications of findings of near-death research literature seem congruent with Spong's continuity view of Jesus, spiritual view of humanity, and call for a new Christianity." According to Gibbs, Spong's "spiritual view of humanity" proposes that "in some ultimate sense" we are all "integral to the light of divine love [that is, God]." Traditional Christian beliefs affirm that we all are made in the image of God (Genesis 1:26-27) and that

[t]hough $\mathrm{He}$ is the Creator and we are creatures, and though God transcends us in being, power, and glory, nevertheless there is some sense in which we are like Him. There is some analogy between God and us. God is an intelligent and moral being. We are also moral agents equipped with a mind, a heart, and a will. These faculties make it possible for us to mirror God's holiness .... (Sproul, 1992, pp. 131-2)

Near-death research likewise has shown that following an NDE, the spiritual nature of humanity is confirmed and strengthened.

Spong's "continuity view of Jesus," however, is not supported by NDE research findings or traditional Christian doctrine. Gibbs writes:

In Spong's view, there is no basic discontinuity between NDErs and Jesus, between persons and god ... . Jesus Christ differed from us in degree rather than in kind .... That Jesus was a profoundly spiritual person - but still a person (defined as a spiritual being having a human experience) - is the premise of the new Christianity called for and envisioned by Spong .... [This premise requires that] we "liberate" Jesus from a literalist misunderstanding and misrepresentation of him as external divinity incarnate, the promised Messiah and sacrificial lamb, different from others not in degree but in kind.

This view is based on widespread rejection, reinterpretation, and "remythologization" of traditional Christianity's view of the Bible and is a theological, not an NDE research-based, claim widely disputed by theologians and biblical scholars (including ten leaders of Spong's own Anglican/Episcopal denomination) (Moore, 1998). The premise rests on the truth or falsehood of Christ's deity. If Jesus were truly unique on Earth as God, then the "discontinuity view" of traditional Christianity is affirmed since NDErs are people and, according to Gibbs, "people are not [and thus are discontinuous with] gods." If Jesus were just "a person," on the other hand, then Spong's "continuity view" would hold sway, since Christ would have been simply a mortal member of the human race. However, NDE research sheds no light on Christ's deity. Thus it is 
misleading for Gibbs to suggest that such research findings are "congruent" (that is, in agreement) with Spong's "call for a new Christianity" and "resonate with Spong's continuity view of Jesus;" just as it would be misleading for me to make similar claims for the congruence or resonance of NDE research with a call for traditional Christianity.

In my work, I have made it clear that, whereas the Bible is my "only reliable yardstick," I have interpreted my research findings within, not in support of or as a call for, a specific theological framework. I have respected this interface between theology and NDE research (Sabom, $2000 \mathrm{a}, \mathrm{pp}$. 254-255) and have spoken out against others, including Christians, who have used NDE research to promote religious agendas (Sabom, 1996; 1998, pp. 165-169; 2000a, pp. 251-255). My conclusion that a general revelation of God may be operative within the NDE is a research-derived conclusion based on structured interviews with NDErs and their responses to Ring's Life Changes Questionnaire (Ring, 1984, p. 122) and the Hoge Intrinsic Religious Motivation Scale (Hoge, 1972). My research has further shown that the NDE is not a significant determinant of new religious beliefs (Sabom, 1998, p. 140). To emphasize my "hands off" approach with NDE-driven theological claims, I ended Light and Death with the plea that one's advocacy of a religion - be it traditional Christian, nonChristian, or "new Christian" not rest on "taking a stand on a vision during the waning moments of life" (Sabom, 1998, p. 223) - and therefore, not rest on NDE research.

Gibbs further writes: "Like Spong's new Christianity, NDE research is at least in principle openminded and evolving .... and each share[s] in principle the ideal of progress through honest and open dialogue." Just how "openminded ... in principle" is Spong's "new Christianity"? Gibbs softly concedes that "[i]n his zeal to excise theism and literalism from Christianity, Spong may have underrepresented paranormal aspects of Jesus' spirituality." And if the paranormal has been "underrepresented," the miraculous has been totally rejected:

This is the crucial issue that Christians face in the battle to rescue the Bible from fundamentalists. Unless the truth of the Bible is lifted out of the literalistic framework that captured it some two thousand years ago, that truth can have for modern women and men no meaning, no credibility, and no appeal. The end of such a warped version of biblical truth is surely death .... This is no exaggeration. The people of this twentieth- and twenty-first-century world of science and technology will not long take seriously a faith story that is proclaimed inside the fantastic symbols of a premodern world, especially if the popular voices of that faith story insist on a literalistic acceptance and interpretation of those symbols. (Spong, 1992, p. 133) 
Spong dismissed the miraculous aspects of Jesus' spirituality as the imaginings of "a nonoperative, prescientific, and clearly false view of the world" (Spong, 1992, p. 26) and of a "prescientific mindset of miracle and magic" (Spong, 1992, p. 37). "When the explosion of scientific knowledge in the sixteenth century began its relentless march to our day," according to Spong, "... the literalness of the story of creation, the supernatural context of most of the biblical drama and the words of miracle and magic disintegrated" (Spong, 1994, p. 17). Traditional Christians Michael Bott and Jonathan Sarfati wrote:

Spong gives no explanation for his denial of the supernatural other than conceptual decree and an appeal to common prejudice. In other words, God doesn't intervene in history because Spong hasn't seen it happen, Spong says it doesn't happen, and we all know it can't happen. A good example of this 'logic' is Spong's discussion of two of his colleagues' views on miracles:

When one Episcopal bishop told me that he accepted the virgin birth story literally because if God wanted to be born of a virgin, He could have arranged that,' or when another said, 'If God created ex nihilo, the virgin birth would be a snap,' I thought to myself, 'How will the church survive in this world with that lack of scholarship among its leaders?' In those statements the bishops were asserting their belief in a God who was in fact a manipulative male person, who would set aside the processes of the world to produce a miracle in order to bring His divine presence into a human enterprise called life, from which this God was clearly separated ....

Spong never tells us why belief in the Virgin Birth or belief in Creatio ex nihilo (creation out of nothing, i.e., no pre-existing matter) entails a lack of scholarship. The statements of the two bishops quoted disparagingly by Spong are perfectly logical - if God is almighty and can create ex nihilo, then arranging for a virgin to bear a child would be easy (i.e., 'a snap'). To declare carte blanche that these things certainly did not happen, just because one believes they cannot, is hardly consistent with a scientific approach. (Bott and Sarfati, 1995, p. 3)

Spong's denial of the miracles of Jesus is a necessary first step in promoting his "new Christianity" since, for traditional Christians, "if Christ has not been raised [that is, resurrected], then [your] preaching is vain, your faith also is vain ... . [and] your faith is worthless ...." (1 Corinthians 15: 14-17). Spong's closedmindedness on this key issue does little to promote Gibbs' desire for "honest and open dialogue" with traditional Christians, whom Spong disparagingly characterized as "anti-intellectual," "afraid of knowledge," and 
"foolish"; and who, according to Spong, "must close off vast portions of their thinking processes or twist their brains into a kind of first-century pretzel in order to maintain their faith system, who play a religious game of 'let's pretend," who hold to "religious delusion" and make "hysterical religious claims," who "appear incapable of thinking outside concrete images," who reveal "the most profound biblical ignorance and the least understanding of the depth of Scripture," and who "are remarkably wrong and remarkably destructive to Christian truth and to a Christian future" (Spong, 1992, pp. 20, 24, 27, 143, 155, 207, 233). The "end of such a warped version of biblical truth is surely death," claimed Spong, for, according to him, traditional Christianity's "drawing power is declining day by day"; its message "no longer has any translatable meaning"; and it "will not last," will "burn itself out in emptiness," "will never survive," and is "sick unto death" (Spong, 1992, pp. 9, 24, 107, 134). Never mind the fact that traditional Christian churches continue to grow and flourish to a far greater degree than do the liberal churches championed by Spong (Hoge, Johnson, and Luidens, 1994) - a fact surprisingly conceded by even Spong himself (Spong, 1992, pp. 35-36). NDE research has further found that following a spiritually-transformative NDE, "[c]hurch attendance increased in conservative Christians, liberal Christians, and Godbelievers alike, with the greatest increase found in those holding the most traditional Christian beliefs" (Sabom, 1998, p. 140).

Anyone who is familiar with NDE research should also recognize that such an "appeal to common prejudice," euphemistically couched as the "twentieth- and twenty-first-century world of science and technology," has frequently been used to reject carte blanche any suggestion that paranormal or spiritual activity may be occurring during an NDE. According to surgery professor Sherwin Nuland:

In the latter part of the twentieth century, we have such a need to be unique, to be special, to be different. You know the thing that unifies so many of these people [that is, NDErs] - they are so narcissistic. It's "Look at me. I saw God. I saw Jesus. I am different." .. Since those experiences are explainable on a perfectly straightforward biological basis, we don't have to invoke supernatural events to explain them. (Nuland, quoted in Corvo, 1996)

And psychology professor Robert Kastenbaum predicted the demise of interest in the NDE more than 25 years ago:

In the supercharged atmosphere of today's fantasy market, the reentry trip, the coming back down to earth can be disappointing. 
The fun is over, but we all may be better off if we start to prepare for the descent from the giddy heights of uncritical thought. If history is any teacher then the current fascination with "life after life" will give way as some new mind trip arises to take its place - as it encounters some hard knocks against reality. (Kastenbaum, 1977, p. 28)

Returning now to Gibbs' question "What do near-death experiencers and Jesus have in common?", Gibbs and I seem to agree that the human spirit imperfectly mirrors the image of God. "Although spiritual effects are sometimes seen in phenomena such as the NDE," according to Gibbs, "most humans are far from divine .... All too evident are our egocentric biases, desires, and motives - modern parlance for our proneness to sin." Using Spong as a springboard, Gibbs then interprets the miracles of Jesus the Divine as paranormal phenomena of Jesus the man - a man who "interpreted his profound spirituality (including his psychic abilities) in theistic terms, to construct a Messianic identity." I, on the other hand, am convinced of the deity of Jesus. The true identity of Jesus is a theological question which must be answered before the "congruence" or "resonance" of NDE research findings and Spong's "new Christianity" can be determined.

Will further deep thinking, academic debate, or "open and honest dialogue" give us the answer? Probably not. According to traditional Christianity, one's conviction in Jesus Christ as Lord and Savior as literally presented in the Bible is beyond the scope of human argument:

John Calvin taught that even though the Scriptures manifest clear and reasonable signs of their divine authority and exhibit sufficient evidence of their divine origin, these evidences do not fully persuade us until or unless they are sealed to our hearts by the inward testimony of the Holy Spirit. Even though we may be able to offer objective and compelling proofs of the truth of Scripture, that is no guarantee that people will believe, yield to, or embrace them. For us to be persuaded of their truth we need the help of the internal testimony of the Spirit .... [This] is not a flight into mysticism or an escape into subjectivism, where personal feelings are elevated to the status of absolute authority .... In His inner witness, the Holy Spirit ... operates upon our spirits to break down and overcome our resistance to God's truth. He moves us to surrender to the clear teaching of God's Word and embrace it with full assurance. (Sproul, 1992, pp. 113-114)

Jesus instructed:

Truly, truly, I say to you, unless one is born of the water and the Spirit, he cannot enter into the kingdom of God. That which is born of 
the flesh is flesh, and that which is born of the Spirit is spirit. Do not marvel that I said to you, "You must be born again." The wind blows where it wishes and you hear the sound of it, but do not know where it comes from and where it is going; so is everyone who is born of the Spirit. (John 3: 2-8)

According to Spong, those who hold traditional Christian beliefs such as these are "foolish" (Spong, 1992, p. 20). Indeed, these beliefs will appear as "foolishness" to the nonbelieving "wise man," "scribe," and "debater of this age" (1 Corinthians 1: 18-20). For the "things of the Spirit of God ... are spiritually appraised" (1 Corinthians 2: 14) and transcend the bounds of human reason and argument.

\section{References}

Bott, M., and Sarfati, J. (1995). What's wrong with Bishop Spong? Laymen rethink the scholarship of John Shelby Spong. [Modified and updated for the Internet with permission from Apologia 4(1), 3-27, 1995.] Retrieved October 4, 2005, from the Answers in Genesis website: http://www.answersingenesis.org/does/1119.asp.

Corvo, D. (exec. prod.). (1996, August 14). Interview with Sherwin Nuland. Dateline NBC [Television broadcast]. New York, NY: NBC News.

Gibbs, J. (2005). What do near-death experiencers and Jesus have in common? The near-death experience and Spong's new Christianity. Journal of Near-Death Studies, this issue.

Hoge, D. R. (1972). A validated intrinsic religious motivation scale. Journal for the Scientific Study of Religion, 11, 369-376.

Hoge, D. R., Johnson B., and Luidens, Donald A. (1994). Vanishing boundaries: The religion of mainline Protestant baby boomers. Louisville, KY: Westminster/ John Knox Press.

Kastenbaum, R. (1977, September). Temptations for the ever after. Human Behavior, pp. 28-33.

Moore, P. C. (ed.). (1998). Can a bishop be wrong? Ten scholars challenge John Shelby Spong. Harrisburg, PA: Morehouse Publishing.

Ring, K (1984). Heading toward omega: In search of the meaning of the near-death experience. New York, NY: William Morrow.

Sabom, M. B. (1996). Review of To hell and back: life after death - Startling new evidence. Journal of Near-Death Studies, 14, 197-209.

Sabom, M. B. (1998). Light and Death: One doctor's fascinating account of near-death experiences. Grand Rapids, MI: Zondervan.

Sabom, M (2000a). Response to Kenneth Ring's "Religious wars in the NDE movement: Some personal reflections on Michael Sabom's Light and Death." Journal of NearDeath Studies, 18, 245-271.

Sabom, M. (2000b). Response to Gracia Fay Ellwood's "Religious experience, religious worldviews, and near-death studies." Journal of Near-Death Studies, 19, $23-44$.

Spong, J. S. (1992). Rescuing the Bible from fundamentalism. San Francisco, CA: HarperSanFrancisco.

Spong, J. S. (1994). Resurrection: Myth or Reality? San Francisco, CA: HarperSanFrancisco.

Sproul, R. C. (1992). Essential truths of the Christian faith. Wheaton, IL: Tyndale House. 